\title{
Kesulitan Guru Pada Pembelajaran Matematika Di Sekolah Dasar
}

\author{
Azra Fauzi ${ }^{1}$, Deni Sawitri ${ }^{2}$, Syahrir $^{3}$ \\ ${ }^{12}$ STKIP Harapan Bima, ${ }^{3}$ Universitas Pendidikan Mandalika \\ fauziazra1@gmail.com,deni.sawitri20@gmail.com,syahrirmandala85@gmail.com
}

\begin{abstract}
Abstrak. Penelitian ini bertujuan untuk mengidentifikasi kesulitan-kesulitan apa saja yang guru hadapi pada proses pembelajaran matematika di sekolah dasar dan bagaimana solusi yang ditawarkan terkait kesulitan yang dihadapi oleh guru pada proses pembelajaran matematika di sekolah dasar. Penelitian ini menggunakan pendekatan kualitatif, sedangkan jenis penelitian yang digunakan adalah diskriptif. Subjek penelitian yaitu guru kelas 6 sekolah dasar. Pengumpulan data dalam penelitian ini yaitu wawancara terstruktur dan dokumentasi. Hasil penelitian menunjukkan bahwa ada beberapa kesulitan yang dialami guru dalam pembelajaran matematika yang meliputi: 1) kurangnya minat belajar siswa pada pelajaran matematika; 2) siswa malas dalam menghafal rumus; 3 ) bedanya system pembelajaran dulu dan sekarang; 4) penggunaan buku tematik yang kurang efektif untuk pembelajaran matematika, dan 5) guru kesulitan mengembangkan materi yang ada dalam buku. Solusi yang ditawarkan terkait kesulitanyang dihadapi yaitu: 1) Guru harus memberikan motivasi belajar kepada siswa; 2) menggunakan media belajar yang tepat; 3 ) penggunaan metode campuran pada saat proses pembelajaran, dan 4) ikut aktif dalam kelompok kerja guru (KKG).
\end{abstract}

Kata kunci: sekolah dasar, kesulitan guru, matematika

\begin{abstract}
This study aims to describe difficulties teachers face in the process of learning mathematics in elemetary schools and how solutions are being developed by teachers in the process of learning mathematics in primary schools. This study uses a qualitative approach, while the type of research used is descriptive. The subjects of the research are grade 6 elementary school teachers. Data collection in this research is structured interview and documentation. The result of the research shows that there are some difficulties that happened in the learning of geometry which include: 1) interest in student learning in math class; 2) students are lazy in memorizing formulas; 3) the difference between learning system first and now; 4) the use of less effective thematic books for mathematics learning, and 5) teachers have difficulty developing the material present in the book. Solutions offered related to difficulties such as: 1) Teachers must provide motivation to learn to students; 2) using appropriate learning media; 3 ) learning methods, and 4) participate actively in the teacher work group (KKG).
\end{abstract}

Keywords: Elementary school, teacher difficulties, mathematics

\section{PENDAHULUAN}

Matematika merupakan salah satu matapelajaran yang diajarkan pada semua jenjang pendidikan mulai dari sekolah dasar (SD), sekolah menengah pertama (SMP), sekolah menengah atas (SMA), hingga perguruan tinggi (Chusna, 2016; Ernawati, 2017; Pebriana, 2017; Puspiadi, 2015; Sari, 2017; Wardana \& Chandra, 2017; Yuliana \& Fajriah, 2013). Tidak hanya didunia pendidikan, matematika juga sangat erat kaitannya dengan kehidupan sehari-hari karena itu matematika sangat penting untuk dipelajari (Listiani, 2015; Pebriana, 2017; Puspiadi, 2015). pembelajaran matematika disekolah dasar sangat penting untuk anak- anak, karena ilmu yang mereka dapatkanpada jenjang ini akan sangat berpengaruh pada jenjang berikutnya.

Proses pembelajaran matematika di sekolah dasar akan membahas tentang konsep-konsep dan materi-materi dasar matematika yang akan membantu siswa pada materi matematika mereka pada jenjang lebih lanjut (Karim, 2011; Mursalin, 2016). Oleh karena itu sangat penting bagi guru untuk menentukan metode pembelajaran yang tepat untuk menanamkan materi matematika sejak SD dengan benar (Safrina, Ikhsan, \& Ahmad, 2014).

Guru mengalami kesulitan dalam memahamkan siswa tentang materi tertentu, 
dalam hal ini guru mengungkapkan bahwa pembelajaran matematika adalah salah satu mata pelajaran yang sulit untuk diajarkan kepada siswa. Permasalahan tersebut dapat dilihat dari kemampuan mereka dalam menyelesaikan masalah matematika yang masih rendah (Karim, 2011; Pranata, 2007). Hasil survey Programme for International Student Assessment (PISA) juga menunjukkan bahwa siswa rendah pada pelajaran matematika.

Kesulitan umum yang dialami oleh guru dalam pembelajaran matematika adalah dalam memahami dan memahamkan konsep dasar materi dengan benar (Idris \& Narayanan, 2011; Tambychik \& Meerah, 2010). Pelajaran matematika merupakan materi yang cukup sulit dipahami, sehingga menyebabkan siswa enggan belajar materi tersebut karena telah berpikiran negatif ketika akan menhadapi pelajaran tersebut (Adolphus, 2011; Safrina et al., 2014). Hal ini dikarenakan juga lemahnya konsep matematika siswa yang diajarkan sejak awal sekolah siswa, sedangkan Pemahaman konsep sangatlah penting pada pembelajaran matematika untuk menunjang kemampuan siswa dalam memahami materi matematika lebih lanjut seperti dalam memecahkan masalah (Geary, 2004; Idris \& Narayanan, 2011; Karim, 2011; Sari, 2017; Tambychik \& Meerah, 2010). Oleh karena itu penting bagi guru dalam memilih dan menggunakan metode maupun media pembelajaran yang tepat sehingga dapat membantu siswa lebih mudah dalam memahami konsep yang dipelajari.

Kesalahpahaman guru dalam membelajarkan matematika di kelas juga perlu diperhatikan, berdasarkan observasi di lapangan masih ada sebagian guru yang menekankan siswanya untuk menghafalkan rumus-rumus matematika yang diberikan, sehingga mengakibatkan siswanya dapat melupakan rumus-rumus tersebut dengan cepat. Ditambah dengan kemajuan teknologi sekarang siswa cenderung mencari jawaban diinternet apabila mendapatkan pertanyaan terkait matematika, baik tentang rumus, cara menyelesaikannya maupun jawaban dari soal yang diberikan oleh guru. Hal ini justru menjadikan guru mengalami kesulitan tersendiri untuk menerangkan materi yang sedikit lebih sulit.

Penelitian ini membahas tentang kesulitan-kesulitan yang dialami oleh guru sekolah dasar pada saat pembelajaran matematika.

\section{KAJIAN PUSTAKA}

Matematika merupakan ilmu universal yang mendasari perkembangan ilmu pengetahuan dan teknologi modern, memajukan daya piker serta analisa manusia (Ruseffendi, 2006). Pembelajaran matematika yang memiliki tingkat kesulitan dan keabstrakan konsep yang lebih tinggi tentu memerlukan cara dan metode komunikasi yang berbeda dengan mata pelajaran lain (Murdiyanto \& Mahatma, 2003).

Kesulitan guru pada pembelajaran matematiuka yaitu memahamkan konsep dasar dari materi yang akan diajarkan (Idris \& Narayanan, 2011; Tambychik \& Meerah, 2010). Pemahaman konsep pada pelajaran matematika sangat penting yang akan sangat membantu baik untuk menunjang kemampuan siswa dalam memahami materi matematika lebih lanjut maupun dalam memecahkan masalah (Geary, 2004; Idris \& Narayanan, 2011; Karim, 2011; Sari, 2017; Tambychik \& Meerah, 2010). Keberhasilan suatu sistem pembelajaran tidak terlepas dari peran guru yang merupakan komponen utama dalam merencanakan dan mendesain proses pembelajaran dengan baik (Ernawati, 2017; Sanjaya, 2012).

\section{METODE PENELITIAN}

Pendekatan penelitian ini adalah kualitatif dan jenisnya deskriptif yang menggunakan data kualitatif dan dideskripsikan untuk menghasilkan gambaran yang jelas dan terperinci mengenai kesulitankesulitan guru dalam pembelajaran matematika. Subjek penelitian ini adalah guru kelas 6 sekolah dasar SDN Dinoyo 4 yang dilaksanakan pada tanggal 13 November 2017.

Data diperoleh melalui wawancara semi terstruktur dan dokumentasi berupa rekaman. Instrument dalam penelitian ini yaitu lembar wawancara semi terstruktur dimana dalam pelaksanaannya lebih bebas 
dengan tujuan untuk menemukan apa saja kesulitan guru selama proses pembelajaran matematika dalam kelas, kemudian peneliti dan guru yang diwawanara diminta untuk memberikan solusi dan ide-ide untuk mengatasi masalah yang berkaitan dengan kesulitan guru dalam proses pembelajaran matematika dikelas 6. Langkah-langkah yang dilakukan dalam menganalisis data yang didapat yaitu dengan menyusun data secara sistematis, menjabarkan, memilih dan memilah data yang penting serta membuat kesimpulan.

\section{HASIL DAN PEMBAHASAN}

Secara umum penelitian bertujuan untuk mengidentifikasi kesulitan-kesulitan guru dalam proses pembelajaran matematika dikelas 6 serta bagaimana cara guru mengatasi kesulitan tersebut. Berdasarkan hasil wawancara dengan guru terdapat beberapa kesulitan yang dialami oleh guru ketika proses pembelajaran matematika:

\section{Kurangnya minat belajar siswa pada} pelajaran matematika

anak-anak itu malas mbak kalau sudah menyangkut pelajaran matematika sulit katanya sulit ditambah kita cuma dapat pelajaran matatika sekilas, kalau tidak dikasi motivasi disela-sela belajarnya yaah wes mereka tidak mau memperhatikan.

Sulitnya belajar matematika menyebabkan minat belajar siswa menurun dan menyebabkan mereka malas untuk memahami setiap materi yang diberika ditambah dengan alokasi waktu belajar matematika merea untuk kurikulum baru ini kurang efektif untuk memahamkan materi matematika secara mendalam. Hal ini menyebabkan guru harus terus mengulang materi tertentu setiap ada kesempatan, baik itu sebelum masuk kelas ataupun pada saat pulang sekolah dan siswa juga rendah dalam prestasi matematika. Indriani (2013) mengungkapkan bahwa rendahnya motivasi belajar siswa menjadi salah satu factor penyebab prestasi belajar siswa yang rendah.

\section{2. siswa malas dalam menghafal rumus}

anak-anak juga sekaran itu lagi malasmalanya kalau menghafal rumus mbak, searang apa-apa kesulitannyakan sukanya nyari diinternet jadi mereka malas hafalin rumus yang diberikan dikelas. Entah ini pengaruh globalisasi atau apa jadi tiap dikasi rumus ndak pernah mau mahamin atau ngafalin jadi saya harus ngulang-ngulang lagi pelajaran yang tidakdiingat sedangkan materi yang akan diajarkan masih banyak yang belum.

Guru mengeluhkan bahwa siswa malas belajar dan menghafal rumus sehingga siswa cepat melupakan materi yang diberikan hari ini. Siswa lebih suka mengandalkan internet untuk membantu mereka dalam menyelesaikan masalah baik itu untuk mencari rumus maupun mencarijawaban langsung jadi, sehingga ketika ada ulangan harian ataupun ulangan semester nilai siswa tidak memuaskan. Dalam hal ini penggunaan internet bernilai negative bagi siswa karena hanya diandalkan ketika ada soal dan mecari jawaban langsung dari internet bukan mengandalkan informasi yang diberikan guru. Hal ini tidak melatih siswa untuk belajar mandiri dan memahami materi yang disampaikan oleh guru. Apalagi ketika siswa akan menjalani ujian nasional, guru harus ekstra menjelaskan dan memahamkan dari awal lagi baik konsep maupun metodemetode penyelesaian soal matematika. Guru jadi harus focus pada materi-materi dasar lagi bukannya try out.

Semangat belajar siswa yang rendah terutama pada pembelajaran matematika menyebabkan guru harus ekstra dalam mengajarkan matematika dan membangkitkn semangat belajar siwa agar tidak selalu mengandalkan yang instan yaitu dengan menggnakan internet.

\section{Bedanya system pembelajaran dulu dan sekarang.}

kelemahannya anak-anak itu yaa gitu mbak dimematika kurang mantap dari kelas sebelumnya, apalagi bedanya system mengajar jaman dulu dan sekarang. Kalau system dulu, mulai dari kelas 3,4 dan 5 sudah diajarkan rumus-rumus bangun rungdan bangun datar itu mateng gituloh mbak karena bidang studinya dibedakan. Kalau sekarang modelnya cuma sepintas terus digabungkan kepelajaran lain jadi anak-anak tidak matangnya disitu,berakibat kekelas-kelas 
berukutnya. Jadi guru susahnya juga disitu menyesuaikan mbak.

Hal yang disebutkan diatas membebankan guru untuk memberikan materi matematika dengan konten lebih berat. Walaupun pada saat masuk jenjang berkutnya siswa akan mendapatkan materi matematika yang lebih lengkap, guru masih mengkhawatirkan siswanya kurang bekal untuk menghadapi materi yang lebih sulit.

Perubahan kurikulum merupakan kesulitan terbesar yang dialami oleh guru SD ketika menerapkan kepada siswa sekolah dasar terutama oleh guru yang telah mengajar sekian tahun, sehingga harus menyesuaikan kurikulum yang ada disaat mereka terbiasa dengan cara mengajar yang lama dan mengharuskan mereka belajar lagi bagaimana cara mengajar yang benar. Hal ini sejalan dengan pendapat (Melania, 2014) yang mengungkapkan guru mengalami banyak kesulitan ketika menerapkan kurikulum untuk sekolah dasar. Diatara kesulitan yang sering dialami oleh guru SD yaitu mulai dari perencaan perangkat pembelajaran dengan pendekatan saintifik, pelaksanaannya dikelas yang berubah dan terkadang tidak susai dengan yang direncanalan, serta penggunaan metode, strategi dan media yang harus digunakan.

4. Penggunaan buku tematik yang kurang efektif untuk pembelajaran matematika kalau buku tematik itu saya rasa kurang cocok mbak untuk anak-anak sekolah dasar, soalnya isis materinya cuma sepintas-sepintas sedangkan dalam pelaksanaan ujian nasional masih dibagi perbidang study. Ditambah dengan isinya yang kurang lengkap jadi guru itu harus mengembangkan sendiri dengan mencari referensi lain yang lebih lengkap untuk diajarkan kesiswa

Penggunaan buku tematik kurang efektif untuk pelajaran matematika karena ketika pelaksanaannya hanya sekilas dan harus mengaitkan dengan materi lain menyebabkan siswa kurang focus dalam menerima materi yang dijelaskan. Walaupun penggunaan buku tematika efektif untuk membantu siswa belajar lebih aktif akan tetapi kurang efektif rasanya apabila disamaratakan pada semua pelajaran. Apalagi untuk peajaran matematika yang cukup sulit siswa pahami sehingga penggunaan buku tematik yang diterapkan dirasa kurang efektif. Siswa sekolah dasar masih harus diarahkan cara berpikir mereka, masih harus ditata apabila diberikan materi yang bercabang akan menbuat mereka kurang focus apalagi tingkat kecerdasan siswa yang berbeda-beda berpengaruh besar pada keberhasilan pencapaian metode tematik. Ketika menerima pembelajaran siswa akan mengalami kesulitan dalam menghubungkan konsep-konsep materi matematika dengan materi matapelajaran lainnya, untuk siswa yang kecerdasannya tinggi mungkin mengalami sedikit kesulitan sehingga tinggal dibimbing sedikit oleh guru dapat membantu mereka, akan tetapi untuk siswa yang kecerdasannya rendah hal ini membutuhkan waktu sedikit lama bagi guru untuk memahamkan siswa tentang materi matematika apalagi yang diberikan hanya sepintas belum lagi materi matematika yang diberikan harus dikaitkan dengan materi lain sehingga menyebabkan siswa tersebut tidak mendapatkan pemantapan materi yang bagus. Hal ini akan menyebakan mereka kesulitan menerima materi matematika dijengjang berikutnya, karena disekolah menengah pertama materi yang dibahas lumayan sulit dan terlalu tinggi sehingga kurang efektif siswa yang hanya menerima materi matematika secara sekilas. Hal ini sejalan dengan beberapa peneliti (Ain \& Kurniawati, 2012; Gularso, 2017; Suwardi, 2015) yang mengungkapkan guru mengalami kesulitan pada pelaksanaan menggunakan tematik.

\section{Guru kesulitan mengembangkan} materi yang ada dalam buku

Materiyang ada dalam buku tematik itu sedikit dan sekilas jadi guru harus mengembangkan sendiri mbak, ditambah kalau kaya saya ginikan cari diinternet susah, mau nyari dibuku lain juga masih kurang. Jadi ya gitu saya kesulitan waktu ngembangin materinya.

Guru kesulitan mengemangkan materi yang berada dalam buku karena materi matematika yang berada dalam buku tematik sangat terbatas dan sepintas menyebabkan guru harus pintar-pintar mencari materi tambahan untuk mengajarkan konsep-konsep 
kepada siswa. Apalagi bagi guru yang sudah lama mengajar di sekolah dasar kesusahan dalam menyesuaikan pengajaran dengan kurikulum yang jauh berbeda dengan kurikulum yang pernah digunakan sebelumnya. Karena pada kurikulum sebelumnya materi matematika adalah matapelajaran yang berdiri sendiri sehingga memiliki banyak bahan yang diajarkan dan guru tinggal memikirkan media apa serta metode apa yang efektif uuntuk mengajarkan sub materi yang akan diberikan. Sedangkan pada kurkulum sekarang, guru harus mencari materi tambahan untuk diajarkan kepada siswa, kemudian mencari media dan strategi pembelajaran yang tepat untuk mengajarkan materi matematika yang bias dikombinasikan dengan materi-materi lainnya.

\section{SIMPULAN}

Berdasarkan hasil penelitian yang dilakukan terdapat beberapa kesulitan yang guru hadapi selama proses pembelajaran matematika iyaitu antaralain: : 1) kurangnya minat belajar siswa pada pelajaran matematika; 2) siswa malas dalam menghafal rumus; 3) bedanya system pembelajaran dulu dan sekarang; 4) penggunaan buku tematik yang kurang efektif untuk pembelajaran matematika, dan 5) guru kesulitan mengembangkan materi yang ada dalam buku. Pentingnya pemahaman konsep matematika bagi siswa sekolah dasar ini menyebabkan guru harus lebih belajar giat agar menemukan solusi-solusi untuk mengatasi kesulitan yang dihadapi, solusi yang ditawarkan oleh peneliti dan guru yaitu: 1) Guru harus memberikan motivasi belajar kepada siswa; 2) menggunakan merode, media dan strategi pembelajaran yang tepat; 3) menggunaan metode campuran pada saat proses pembelajaran, dan 4) ikut aktif dalam kelompok kerja guru (KKG) yang telah di tetapkan.

\section{Saran}

Pentingnya pemahaman konsep matematika bagi siswa sekolah dasar ini menyebabkan guru harus berusaha menemukan solusi-solusi untuk mengatasi kesulitan yang dihadapi. Berikut merupakan solusi-solusi yang dapat guru terapkan dikelas untuk membantu guru dalam mengajarkan materi matematika dikelas. Berdasarkan hasil wawancara dengan guru kelas VI SDN Dinoyo 4 Malang, solusi yang digunakan oleh guru untuk mengatasi kesulitan-kesulitan dalam proses pembelajaran matematika dalam kelas sebagai berikut:

\section{Memberikan motivasi belajar kepada siswa}

Berdasarkan minat belajar siswa yang kurang, sebagai guru harus sering-sering memberikan motivasi tentang pentingnya belajar matematika bagi kehidupan seharihari. Guru juga harus membangkitkan motivasi belajar siswa dengan terus memberikan ulasan-ulasan materi dengan metode-metode dan strategi belajar yang menarik sehingga memunculkan rasa penasaran serta minat siswa untuk mengetahui sesuatu.

\section{Menggunakan media belajar yang tepat}

Pada proses pembelajaran matematika penggunaan media sangat membantu guru dalam memahamkan kepada siswa terutama tenang konsep materi matematika yang akan dipelajari.

\section{Penggunaan metode campuran}

Penggunaan metode campuran akan sangat efektif bagi guru yang kesulitan membelajarkan tematik dikelas. Karena tematik merupakan system pembelajaran yang saling berkaitan antara materi yang satu dengan yang lainnya maka Penggunaan metode ini membantu guru selama poses mengajar karena penggunaan metode campuran dapat menyesuaikan kebutuhan guru dan kebutuhan siswa. Sangat disarankan bagi guru yang masih kesulitan dalam menerapkan metode ceramah dikelas untuk mulai mencoba menerapkan metode campuran. Hal ini dapat membantu siswa lebih aktif dalam belajar dan guru tidak kesulitan dalam menyesuaikan metode pembelajaran apa yang dapat mencakup semua materi.

\section{Ikut aktif dalam kelompok kerja guru (KKG)}

Kegiatan kelompok kerja guru merupakan wadah yang berfungsi sebagai penunjang kegiatan belajar mengajar dikelas yang membahas tentang kesulitan-kesulitan guru, strategi pembelajaran, membuat alat peraga, 
membuat lembar kerja, lembar tugas, serta membahas masalah-masalah apa saja yang dialami setiap guru dikelas dan kemudian mencari solusi yang tepat untuk mengatasi masalah yang ada. Hal ini diungkapkan oleh beberapa peneliti yang mengungkapkan bahwa KKG merupakan salah satu cara pemerintah untuk membentuk guru yang profesional (Alwi, 2009; Cajkler \& Wood, 2016; Purnanda, 2013; Studi et al., 2016; Sutrisno, 2016; Taryono, 2006). Sehingga Sangat dianjurkan bagi guru-guru lain untuk ikut aktif dalam KKG, karena selain mengurangi beban guru dalam masalah proses pembelajaran, KKG juga membantu guru untuk mengetahui informasi-informasi baru terkait dunia pendidikan khususnya bagaimana perkembangan matematika disekolah lain.

kelompok kerja guru merupakan solusi terpenting dari semua solusi yang diberikan karena dalam KKG akan banyak ide dari sesama yang membantu guru dalam menyelesaikan masalah terkait pelajaran yang diterapkan dikelas.

\section{DAFTAR PUSTAKA}

Adolphus, T. (2011). Problems of teaching and learning of geometry in secondary schools in Rivers State, Nigeria. International Journal of Emerging Sciences, 1(2), 143-152.

Ain, N., \& Kurniawati, M. (2012). Implementasi Kurikulum KTSP: Pembelajaran Tematik Di Sekolah Dasar Nurul, 316-328.

Alwi, M. (2009). Peran Kelompok Kerja Guru ( Kkg ) Dalam Meningkatkan Profesional Guru Sains Sekolah. Jurnal EducatiO, 4(2), 101-117.

Cajkler, W., \& Wood, P. (2016). Mentors and student-teachers "lesson studying" in initial teacher education. International Journal for Lesson and Learning Studies. https://doi.org/10.1108/IJLLS04-2015-0015

Chusna, F. A. (2016). Upaya Guru Mengatasi Kesulitan Belajar Matematika Pada Siswa Kelas IV SD Negeri 1 Pangenrejo. Universitas Negeri Yogyakarta.

Ernawati, D. (2017). Peran Guru Kelas Dalam Menangani Kesulitan Belajar
Matematika Pada Siswa. Universitas PGRI Yogyakarta. Yogyakarta.

Geary, D. C. (2004). Mathematics and Learning Disabilities. Journal of Learning Disabilities, 37(1), 4-15. https://doi.org/10.1177/00222194040370 010201

Gularso, D. (2017). Analisis kesulitan dalam perencanaan pembelajaran tematik di sekolah dasar. Jurnal Pendidikan Sekolah Dasar, 3(2).

Idris, N., \& Narayanan, L. M. (2011). Error Patterns in Addition and Subtraction of Fractions among Form Two Students. Journal of Mathematics Education, 4(2), 35-54. Retrieved from http://educationforatoz.com/images/Idris. pdf

Indriani, A. (2013). Pengaruh Motivasi Belajar Siswa Kelas V Terhadap Prestasi Belajar Matematika Di Sd Negeri Bejirejo Kecamatan Kunduran Kabupaten Blora. Jurnal Pendidikan Matematika, 4(2), 134-139.

Karim, A. (2011). Penerapan Metode Penemuan Terbimbing Dalam Pembelajaran Matematika Untuk Meningkatkan Pemahaman Konsep Dan Kemampuan Berpikir Kritis Siswa Sekolah Dasar. Jurnal Penelitian Pendidikan, Edisi Khus(2), 154-163.

Listiani, N. (2015). Pengaruh Kesiapan Belajar Dan Kecerdasan Spiritual Siswa Terhadap Motivasi Belajar Matematika Di Smp Negeri 16 Kota Cirebon. IAIN Syekh Nurjati Cirebon.

Melania, L. (2014). Analisis Kesulitan Guru Sekolah Dasar Dalam Implementasi Pendekatan Saintifik Pada Pembelajaran Tema Indahnya Persahabatan Di Kelas 3 Sd Gugus 3 Lowokwaru Kota Malang. Proseding SEMNAS KSDP: Konstelasi Pendidikan Dan Kebudayaan Indonesia Di Era Globalisasi, 239-246.

Murdiyanto, T., \& Mahatma, Y. (2003). Pengembangan Alat Peraga Matematika Untuk Meningkatkan Minat Dan Motivasi Belajar Matematika Siswa Sekolah Dasar. Jurnal Sarwita, 11(1), 356-362.

https://doi.org/10.7498/aps/62.010302 
Mursalin. (2016). Pembelajaran Geometri Bidang Datar di Sekolah Dasar Berorientasi Teori Belajar Piaget. DIKMA (Jurnal Pendidikan Matematika), 4(2), 250-258.

Pebriana, P. H. (2017). Peningkatan Hasil Belajar Matematika Dengan Menerapkan Pendekatan Pendidikan Matematika Realistik Indonesia ( Pmri ) Pada Siswa Kelas V Sdn 003 Bangkinang Pendidikan Matematika Realistik Indonesia ( Pmri ). Hasil Belajar Siswa Mengalami Peningkatan Dari. Jurnal Cendekia: Jurnal Pendidikan Matematika, 1(1), 68-79.

Pranata, O. H. (2007). Pembelajaran Berdasarkan Tahap Belajar Van Hiele untuk Membantu Pemahaman Siswa Sekolah Dasar dalam Konsep Geometri Bangun Datar. Universitas Pendidikan Indonesia.

Purnanda, A. (2013). Pelaksanaan Fungsi Kelompok Kerja Guru ( $\mathrm{Kkg}$ ) Di Sekolah Dasar Negeri ( Sdn ) Kecamatan Sungai Tarab. Jurnal Administrasi Pendidikan, 1, 1-8.

Puspiadi, G. A. (2015). Analisis Kemampuan Koneksi Matematika Siswa Studi Kasus Di Kelas Vii Smpn Satu Atap 2 Terisi Indramayu. IAIN Syekh Nurjati Cirebon.

Ruseffendi. (2006). Pengantar Kepada Membantu Guru Mengembangkan Kompetensinya dalam Pengajaran Matematika untuk Meningkatkan CBSA. Bandung: Tarsito.

Safrina, K., Ikhsan, M., \& Ahmad, A. (2014). Peningkatan Kemampuan Pemecahan Masalah Geometri melalui Pembelajaran Kooperatif Berbasis Teori Van Hiele. Jurnal Didaktik Matematika, 1(1), 9-20.

Sanjaya, W. (2012). Perencanaan dan Desain Sistem Pembelajaran. Jakarta: KENCANA PRENADA MEDIA GRUP.

Sari, P. (2017). Pemahaman Konsep Matematika Siswa Pada Materi Besar Sudut Melalui Pendekatan PMRI. Jurnal GANTANG, II(1), 41-51.

Studi, P., Pendidikan, M. M., Keguruan, F., Ilmu, D. A. N., Kristen, U., \& Wacana, S. (2016). PENGEMBANGAN MODEL MANAJEMEN KELOMPOK KERJA
GURU （ KKG ） UNTUK MENINGKATKAN KOMPETENSI.

Sutrisno, A. (2016). Pemberdayaan Kelompok Kerja Guru ( Kkg ) Pada Gugus Hasanudin Di Kecamatan Karangrayung. Universitas Muhammadiyah Surakarta.

Suwardi. (2015). Kendala Implementasi Pembelajaran Tematik di Madrasah Ibtidaiyah Swasta. PROSIDING SEMINAR NASIONAL PENDIDIKAN: Meretas Sukses Publikasi Ilmiah Bidang Pendidikan Jurnal Bereputasi, 267-273.

Tambychik, T., \& Meerah, T. S. M. (2010). Students' difficulties in mathematics problem-solving: What do they say? Procedia - Social and Behavioral Sciences, 8(5), 142-151. https://doi.org/10.1016/j.sbspro.2010.12. 020

Taryono. (2006). Pelaksanaan Program Kegiatan Kelompok Kerja Guru Pendidikan Jasmani Profesional Di Kecamatan Pedurungan Kota Semarang. Wardana, P. E. P., \& Chandra, T. D. (2017). Penerapan Pembelajaran Problem Posing Untuk Meningkatkan Kemampuan Bertanya Siswa Kelas Vii-G Smp Negeri 9 Malang. Jurnal Kajian Pembelajaran Matematika, 1(April), 52-63.

Yuliana, I., \& Fajriah, N. (2013). Penerapan Metode Belajar PQ4R Dalam Pembelajaran Matematika Kelas VII SMP. EDU-MATH Jurnal Pendidikan Matematika, 1(1), 27-33. 